\title{
Android-based Stunting Child Nutrition Application (GiAS) to Assess Macro-nutrients, Zinc, and Calcium in Stunting and Non-stunting Under Two Children
}

\author{
Fajarini Putri Hidayat, ${ }^{1}$ Ma'mun Sutisna,,,2 Roni Rowawi, ${ }^{1,3}$ Hidayat Wijayanegara,,,4 \\ Herry Garna, ${ }^{1,5}$ Atie Rachmiatie ${ }^{1,6}$ \\ ${ }^{1}$ Applied Midwifery Master Study Program, STIKes Dharma Husada, Bandung, Indonesia, ${ }^{2}$ Politeknik Negeri \\ Bandung, Bandung, Indonesia, ${ }^{3} \mathrm{RS}$ Immanuel, Bandung, Indonesia, ${ }^{4}$ Department of Obstetrics and Gynecology, \\ Faculty of Medicine, Universitas Islam Bandung, Bandung, Indonesia, ${ }^{5}$ Department of Child Health, \\ Faculty of Medicine, Universitas Islam Bandung, Bandung, Indonesia, ${ }^{6}$ Department of Communication, \\ Faculty of Communication, Universitas Islam Bandung, Bandung, Indonesia
}

\begin{abstract}
Stunted children will have normal cognitive ability if nutrition is improved. The rapid brain growth in the first 1,00o days of life means that children should not be malnourished. Stunting is generally caused by a lack of macronutrients (carbohydrates, protein, and fat) and micronutrients (calcium and zinc). The mobile application called stunting child nutrition (GiAS) has features that can detect stunting, monitor toddler growth, recommend daily menus for toddlers, nutritional adequacy rate (RDA) in 2019, and others. The purpose of this study was to make it easier to distinguish macronutrients, zinc, and calcium from stunting and non-stunting children aged 12-24 months using the GiAS android application. It is conducted at the Citeureup Public Health Center, Cimahi city, for June-July 2020. The sampling technique was a simple random sampling of 88 respondents. This type of research is an observational analytic with a statistical test is a cross-sectional design. The results of the study using the MannWhitney test showed differences in carbohydrates $(84.99 \pm 26.31 \mathrm{vs} 151.16 \pm 68.43, \mathrm{p}=0.001)$, protein (30.81 $\pm 11.03 \mathrm{vs}$ $60.55 \pm 38.43, \mathrm{p}=0.001)$, fat $(32.80 \pm 15.39$ vs $64.84 \pm 47.81, \mathrm{p}=0.001)$, and calcium $(0.55 \pm 0.40$ vs $1.43 \pm 1.16, \mathrm{p}=0.001)$ and there is similarity of zinc $(0.005 \pm 0.004$ vs $0.010 \pm 0.016, p=0.084)$ after 7 days of using the GiAS application between stunting and non-stunting children. The probability value <0.05 means that the application can compare macronutrients, zinc, and calcium between stunted and non-stunted children on the $7^{\text {th }}$ day. Chi-square analysis showed an increase in children's weight and height under five at two weeks and one month $(\mathrm{p}=0.001)$. In conclusion, the comparison of macronutrients, zinc, calcium in stunting and non-stunting children aged 12-24 months can be differentiated using the GiAS application.
\end{abstract}

Key words: GiAS applications, nutrient, stunting, toddlers

\section{Aplikasi Gizi Anak Stunting (GiAS) berbasis Android untuk Menilai Zat Gizi Makro, Zinc, dan Kalsium pada Anak Stunting dan Non-stunting}

\begin{abstract}
Abstrak
Anak stunting akan memiliki kognitif yang normal jika dilakukan perbaikan gizi yang optimal. Pertumbuhan otak yang pesat di 1.000 hari pertama kehidupan menjadikan anak tidak boleh kekurangan nutrisi. Stunting umumnya kekurangan zat gizi makro (karbohidrat, protein, dan lemak) serta zat gizi mikro (kalsium dan zinc). Aplikasi mobile bernama gizi anak stunting (GiAS) memiliki fitur yang dapat mendeteksi stunting, memantau pertumbuhan balita, merekomendasikan menu harian untuk balita, angka kecukupan gizi (AKG) tahun 2019, dan lainnya. Tujuan penelitian ini adalah kemudahan membedakan zat gizi makro, zinc, dan kalsium anak stunting dengan non-stunting usia 12-24 bulan menggunakan aplikasi android GiAS di Puskesmas Citeureup Kota Cimahi periode Juni-Juli 2020. Teknik pengambilan sampel adalah simpel random sampling sebanyak 88 responden. Jenis penelitian ini adalah analitik observasional dengan uji statistik adalah desain cross-sectional $(\alpha=0,05)$. Hasil penelitian menggunakan Uji Mann-Whitney terdapat perbedaan karbohidrat $(84,99 \pm 26,31$ vs $151,16 \pm 68,43 ; p=0,001)$, protein $(30,81 \pm 11,03$ vs $60,55 \pm 38,43 ; \mathrm{p}=0,001)$, lemak $(32,80 \pm 15,39$ vs $64,84 \pm 47,81 ; \mathrm{p}=0,001)$, dan kalsium $(0,55 \pm 0,40$ vs $1,43 \pm 1,16$; $\mathrm{p}=0,001)$ serta ada persamaan zinc $(0,005 \pm 0,004$ vs $0,010 \pm 0,016 ; p=0,084)$ sesudah 7 hari penggunaan aplikasi GiAS antara anak stunting dan non-stunting. Nilai probabilitas <0,05 berarti aplikasi dapat membandingkan zat gizi makro, zinc, dan kalsium antara anak stunting dan non-stunting pada hari ke-7. Analisis chi-square terlihat peningkatan berat badan dan tinggi badan balita pada 2 minggu dan 1 bulan ( $p=0,001)$. Simpulan, komparasi zat gizi makro, zinc, kalsium anak stunting dan non-stunting usia 12-24 bulan dapat dibedakan menggunakan aplikasi GiAS.
\end{abstract}

Kata kunci: Aplikasi GiAS, balita, stunting, zat gizi

Received: 21 September 2020; Revised: 6 April 2021; Accepted: 8 April 2021; Published: 30 April 2021

Correspondence: Fajarini Putri Hidayat. Applied Midwifery Study Program, STIKes Dharma Husada. Jln. Terusan Jakarta No. 71-75, Bandung 40282, West Java, Indonesia. E-mail: fajrin.putri@gmail.com 


\section{Introduction}

Micronutrient deficiency contributes seriously to child morbidity and mortality. Fulfilling the needs of micronutrients or micronutrients can be obtained from food, fortified foods, and direct supplementation. The low food quality causes the deficiency of various vitamins and minerals in toddlerhood. ${ }^{1}$

Carbohydrates are the primary source of energy needed for activities, while excess carbohydrates in the body will be stored in fat as a reserve source of energy. Fat in the body is useful as a source of energy and dissolves vitamins so that it can be easily absorbed by the intestine. ${ }^{2}$

Protein is a macro substance that plays a vital role in the body's metabolic processes and enzyme function. Excess or lack of protein in the first 1,000 days will negatively affect the body, such as growth and maintenance of disturbed tissue, disturbed fluid balance regulation, reduced antibodies, and disturbed nutrient transport. ${ }^{3}$

Zinc is a micromineral that has a role in the enzyme part of the body's metabolism, growth hormone production, and as an antioxidant for immune function. ${ }^{4}$

Lack of calcium in children causes adaptation to bone formation controlled by growth hormone, thyroid, calcitonin, parathyroid hormone (PTH), sex hormones, calcium, phosphorus, vitamin A, and D. ${ }^{5}$

Stunting describes chronic undernutrition status during growth and development since early life. ${ }^{6}$ Editing detection needs to be done, especially by parents in daily nutritional intake, especially in children who have received complementary foods. There are differences in macronutrients and micro-nutrient intake for stunted and nonstunted children, both in terms of the amount and diversity of food consumption. ${ }^{7}$

According to the World Health Organization (WHO), if breast milk is not sufficient to meet children's nutritional needs, complementary foods must be added to their diet. In general, breast milk alone does not meet the nutritional needs of children at the age of 6 months to 1824 months because the supply of breast milk has decreased and must be supplemented with complementary foods and is a period that is prone to malnutrition. ${ }^{8}$

Consumption of food or nutrients that enter can be known by carrying out food recall or food memories to determine that macro and micronutrients are in the body. So far, recall food has only been carried out by health workers or nutritionists to determine a person's nutritional status by recording the type and amount of food consumed during the past 24 hours. The mother or caregiver is asked to describe everything she ate and drank during the past 24 hours. Usually, it starts from when the child woke up yesterday until the child went to sleep again. ${ }^{9}$

The development of digital technology is increasingly rapid. The GiAS application designed by researchers is an application or digitization of children's nutrition records. Parents can observe the past nutrition when their child having development problem, and it can also be used to prevent development problem because parents can recall food intake easier with the help of an android cellphone. ${ }^{9,10}$

Another advantage of the GiAS application is that it is easy to fill in children's anthropometric data. Streamlines the time that midwives, nutrition officers, cadres, and parents use to detect stunting and monitor children's growth. It also provides food ingredients that will increase children's growth in the GiAS application. ${ }^{11,12}$

The purpose of this study was to observe the application of nutrition for stunting children (GiAS) whether it is easier to distinguish macronutrients, zinc, and calcium from stunting and non-stunting children aged 12-24 months.

\section{Methods}

This research is an analytical study with a cross-sectional study design with two groups of stunting and non-stunting toddlers aged 12-24 months in the working area of the Citeureup Public Health Center, Cimahi city, from June to July 2020. Random sampling was carried out to obtain a total sample of 88 subjects, 45 stunted children and 43 non-stunting children. Subjects were parents and toddlers aged 12-24 months who met the inclusion criteria and stated their willingness to participate in the study after obtaining information by signing informed consent.

The instruments used to collect data measured children's weight and height and an android-based application of stunting child nutrition (GiAS). Both groups of children under five were measured for weight and height at the start of the study after two weeks and a month. GiAS application to determine macronutrients (carbohydrates, protein, and fat), zinc, and calcium from the recommended dietary allowance (RDA) in 2019 
and determine stunted and non-stunted children seen from the graph of height growth per age, as well as food menu recommendations contained in the menu application according to the 2020 mother and child health $(\mathrm{MCH})$ book draft. ${ }^{13}$ The inclusion criteria are parents and toddlers aged 12-24 months. The exclusion criteria for children aged 12-24 months who were sick.

This research's ethical permission was obtained from the Health Ethics Committee of STIKes Dharma Husada Bandung Number 01/ KEPK/SDHB/B/VII/202O.

\section{Results}

Respondents were almost the same number of males with females ( $51 \%$ vs $49 \%$ ), while more females were non-stunting ( $56 \%$ vs $44 \%$. The mean mean age of non-stunting children with stunting (16.72 months vs 17.77 months, $p=0.234$ ). The weight gain of non-stunting children after 2 weeks was heavier than stunted children (260 $\mathrm{g}$ vs $50 \mathrm{~g}, \mathrm{p}=0.001)$, as well as after one month (410 g vs $160 \mathrm{~g}, \mathrm{p}=0.001$ ). The height increase in stunting children was greater than that of nonstunting children after two weeks $(2.69 \mathrm{~cm}$ vs 0.6 $\mathrm{cm}, \mathrm{p}=0.001)$ and after one month $(2.89 \mathrm{~cm}$ vs $0.84 \mathrm{~cm}, \mathrm{p}=0.001)$. The increase in body weight of non-stunting and stunting children at two weeks $(\mathrm{p}=0.446 \mathrm{vs} \mathrm{p}=0.001)$ and at one month ( $p=0.001$ vs $p=0.001)$, the increase in height for non-stunting and stunting children after two weeks $(p=0.001$ vs $p=0.001)$, and after one month $(\mathrm{p}=0.001 \mathrm{vs} \mathrm{p}=0.001)$.

Table 2 describes the results of normality tests and comparison of micronutrients, zinc, and calcium in stunted and non-stunted children using the GiAS application. The normality test shows that the data distribution is not normally distributed with a probability value below 0.05 , so the comparison test uses the Mann-Whitney test.

Table 1 Stunting and Non-stunting Respondents Characteristics

\begin{tabular}{|c|c|c|c|c|c|}
\hline \multirow{2}{*}{ Children Characteristic } & \multicolumn{2}{|c|}{ Non-stunting } & \multicolumn{2}{|c|}{ Stunting } & \multirow{2}{*}{$\mathbf{p}^{*}$} \\
\hline & $n=43(\%)$ & Gained & $n=45(\%)$ & Gained & \\
\hline $\begin{array}{l}\text { Gender } \\
\text { Male } \\
\text { Female }\end{array}$ & $\begin{array}{l}19(44) \\
24(56)\end{array}$ & & $\begin{array}{l}23(51) \\
22(49)\end{array}$ & & 0.516 \\
\hline Aged (month) $($ mean \pm SD) & $16.72 \pm 4.36$ & & $17 \cdot 77 \pm 4.12$ & & 0.234 \\
\hline $\begin{array}{l}\text { Weight }(\mathrm{kg})(\text { mean } \pm \text { SD }) \\
\text { Start } \\
\text { After } 2 \text { weeks } \\
\text { After } 1 \text { months }\end{array}$ & $\begin{array}{c}9.91 \pm 2.00 \\
10.17 \pm 1.79 \\
10.32 \pm 1.80\end{array}$ & $\begin{array}{l}260 \mathrm{~g}, \mathrm{p}^{*}=0.446 \\
410 \mathrm{~g}, \mathrm{p}^{*}=0.001\end{array}$ & $\begin{array}{l}8.88 \pm 1.10 \\
8.93 \pm 1.27 \\
9.04 \pm 1.26\end{array}$ & $\begin{array}{c}50 \mathrm{~g}, \mathrm{p}^{*}=0.001 \\
160 \mathrm{~g}, \mathrm{p}^{*}=0.001\end{array}$ & $\begin{array}{l}0.001 \\
0.001\end{array}$ \\
\hline $\begin{array}{l}\text { Height }(\mathrm{cm})(\text { mean } \pm \text { SD }) \\
\text { Start } \\
\text { After } 2 \text { weeks } \\
\text { After } 1 \text { months }\end{array}$ & $\begin{array}{c}78.02 \pm 5.3 \\
78.62 \pm 5.07 \\
78.86 \pm 50.04\end{array}$ & $\begin{array}{c}0.6 \mathrm{~cm}, \mathrm{p}^{*}=0.001 \\
0.84 \mathrm{~cm}, \mathrm{p}^{*}=0.001\end{array}$ & $\begin{array}{l}71.56 \pm 6.45 \\
74.25 \pm 4.23 \\
74.45 \pm 4.16\end{array}$ & $\begin{array}{l}2.69 \mathrm{~cm}, \mathrm{p}^{*}=0.001 \\
2.89 \mathrm{~cm}, \mathrm{p}^{*}=0.001\end{array}$ & 0.001 \\
\hline
\end{tabular}

Note: ${ }^{*}$ chi-square test

Table 2 Normality Test of Macro Nutrients, Zinc, and Calcium in Stunting Children and Non-stunting Ages of 12-24 Months Using the GiAS Application

\begin{tabular}{lccc}
\hline \multirow{2}{*}{ Variables } & \multicolumn{2}{c}{ p Value Normality Test } & \multirow{2}{*}{ Explanation } \\
\cline { 2 - 3 } & Stunting & Non-stunting & \\
\hline Carbohydrate & 0.007 & 0.001 & Not normal \\
Fat & 0.000 & 0.001 & Not normal \\
Protein & 0.047 & 0.001 & Not normal \\
Calcium & 0.000 & 0.001 & Not normal \\
Zinc & 0.000 & 0.001 & Not normal \\
\hline
\end{tabular}

Note: Mann-Whitney test 
Table 3 Comparative Test of Macro Nutrients, Zinc, and Calcium After 2 Weeks of Stunted Children with Non-stunting Ages of 12-24 Months Using the GiAS Application

\begin{tabular}{lccc}
\hline $\begin{array}{l}\text { Nutrients } \\
\text { (grams) }\end{array}$ & $\begin{array}{c}\text { Stunting } \\
\text { Mean } \pm \text { SD }\end{array}$ & $\begin{array}{c}\text { Non-stunting } \\
\text { Mean } \pm \text { SD }\end{array}$ & p Value \\
\hline Carbohydrate & $84.99 \pm 26.31$ & $151.16 \pm 68.43$ & 0.001 \\
Fat & $32.80 \pm 15.39$ & $64.84 \pm 47.81$ & 0.001 \\
Protein & $30.81 \pm 11.03$ & $60.55 \pm 38.43$ & 0.001 \\
Calcium & $0.55 \pm 0.40$ & $1.43 \pm 1.16$ & 0.001 \\
Zinc & $0.005 \pm 0.004$ & $0.010 \pm 0.016$ & 0.084 \\
\hline
\end{tabular}

Note: Mann-Whitney test

Based on Table 3, it can be seen that the comparative test of research variables after two weeks in stunted and non-stunted children the mean of carbohydrate, fat, protein, calcium and zinc nutrients as follows: carbohydrate $(84.99$ $\mathrm{g}$ vs $151.16 \mathrm{~g}, \mathrm{p}=0.001)$, as well as fat $(32.80 \mathrm{~g}$ vs $64.84 \mathrm{~g}, \mathrm{p}=0.001$ ), protein ( $30.81 \mathrm{~g}$ vs 60.55 $\mathrm{g}, \mathrm{p}=0.001$ ), and calcium (0.55 mg vs 1.43 $\mathrm{mg}, \mathrm{p}=0.001)$ and zinc (0.005 $\mathrm{mg}$ vs $0.01 \mathrm{mg}$, $\mathrm{p}=0.084$ ).

\section{Discussion}

The respondents' characteristics in this study included the child's characteristics (gender, age of the child at the time of the study, initial body weight, two weeks and one month, and initial height, two weeks and one month). There was an increase in body weight and height in both groups after using the GiAS application. The application can detect macronutrients (protein, carbohydrates, and fats) and zinc, and calcium.

The analysis results showed a difference between the nutrition of stunting and nonstunting children using the GiAS application. The GiAS application is an application that can help parents, cadres, and health workers to quickly detect nutrition problems in toddlers-nutrients such as carbohydrates, protein, fat, zinc, and calcium. This application can also detect stunting or non-stunting toddlers by looking at the growth chart, one of the features in the GiAS application. According to their age, nutritional needs can be seen from the nutritional graph and adjusting the calories needed by toddlers. This application lists food ingredients adjusted to the type of nutrition and food ingredients that can be searched according to the Indonesian food composition table issued by the Ministry of Health Republic of Indonesia. This application also includes recommendations for food menus whose composition is almost the same as the $2020 \mathrm{MCH}$ book draft, and there are other information needs regarding health. ${ }^{14,15}$

The GiAS application can compare macronutrients, zinc, and calcium, that the nutrients of stunting and non-stunting children are different with a probability value of $\mathrm{p}<0.05$. There were differences in carbohydrate, protein, fat, and calcium nutrients between non-stunting and stunting children after two weeks, except for zinc.

The results showed that the carbohydrate needs of stunted and non-stunted children had a significant difference in that the carbohydrate needs of children aged 12-24 months were 215 grams/day according to the 2019 RDA. while 84.99 grams of stunting children only half the RDA. ${ }^{14,15}$

Research according to Ayuningtyas et al., ${ }^{16}$ there is a relationship between energy intake and the incidence of stunting in children under five. It is found that less energy intake primarily affects the incidence of stunting.

Astutik et al. ${ }^{17}$ stated a significant relationship between energy intake and stunting because almost $50 \%$ of energy needs are adequately met.

Carbohydrates in the human body are useful as the primary source of energy needed for activities. In contrast, excess carbohydrates in the body will be stored in fat as a reserve source of energy. When the body lacks energy intake, the body will change these fat reserves. This will affect a person's nutritional status. ${ }^{3,17,18}$

Fat nutrition for stunted children and nonstunted children was significantly different. Fat for stunted children is 32.80 grams, and nonstunting is 64.84 grams. Fat for non-stunting children exceed the recommended fat nutrients 
for the $2019 \mathrm{RDA}$, which is 45 grams/day while stunting needs fat is still less than the RDA. ${ }^{14}$ Fat in the body is useful as a source of energy and dissolves the carrying vitamins $\mathrm{A}, \mathrm{D}, \mathrm{E}$, and $\mathrm{K}$ so that the intestines can easily absorb it. ${ }^{2}$ Lack of fat in the body will reduce energy availability and lead to catabolism (overhaul) of protein, while a lack of fatty acids will interfere with growth. ${ }^{3}$ The highest sources of fat are oil, butter, margarine, and others. It is better if providing food for children, especially in the first 1,000 days of life, is accompanied by a source of fat. ${ }^{15}$ Ayuningtyas et al. ${ }^{16}$ stated an association of less fat intake with the incidence of stunting. It is inversely proportional to the research of Isnainy et al., ${ }^{18}$ the average daily fat needs of stunted children are well fulfilled or following the 2013 RDA.

The results showed that the children's nutritional intake for seven days, on average, only a few stunted children ate daily fats such as margarine, butter, coconut milk, cooking oil, and others. In contrast, non-stunting children eat more foods that contain lots of high fat, such as fried and fast food (sausages, nuggets, and others). Only a few eat unsaturated fats such as soybeans and fish. Following the research of Isnainy et al., ${ }^{18}$ the consumption of unsaturated fats, especially polyunsaturated fatty acids (PUFA), plays an essential role in fat transport and metabolism, immune function, and maintains the function and integrity of cell membranes. One of the consequences of less fat consumption is a lack of vitamin A because vitamin A is a vitamin that helps absorb carotenoids. It also functions for immunity, epithelial cell integrity, growth and development, vision, and reproduction.

Based on the comparative test of protein nutrition variables in stunted children 30.80 grams and non-stunted children 60.55 grams, both have a significant difference. However, if seen from the $2019 \mathrm{RDA}$, the protein needed for toddlers aged 12-24 months is 20 grams per day, the daily protein needs of both stunting and nonstunting children have met the RDA standard.

Following the research of Ayuningtyas et al., ${ }^{16}$ there is a significant relationship between the level of protein intake and the incidence of stunting. In contrast to Aryati et al. ${ }^{4}$ the average protein intake from $2 \times 24$ hours recalls food processing was 23.38 grams. This figure is still below the $\mathrm{RDA}$, the RDA for 2013, the daily protein intake for under-five children is 26 grams when viewed from the $\mathrm{RDA}$ for 2019, the protein intake is sufficient because the protein requirement for the 2019 RDA is 20 grams/day.

The study of daily nutritional intake at 12-24 months of stunting and non-stunting children consumed an excellent average of protein by including vegetable protein and animal protein. The average of parents of stunted children after using the application included animal protein every time the child ate to meet the needs of essential amino acids.

Based on the research results on calcium nutrition, there is a significant difference between stunting and non-stunting children, with the mean value of stunted children with 0.55 grams and non-stunting children 1.43 grams. In contrast, the normal value of calcium nutrition according to the $2019 \mathrm{RDA}$ is $650 \mathrm{mg}$ or 0,65 grams, which means that non-stunted children have average calcium exceeding the child's daily calcium needs, while for stunting it is still insufficient, but almost fulfills their daily needs because children aged 12-24 months on average are still breastfeeding or receiving formula milk.

In contrast to the study, Kurniasari et al. ${ }^{5}$ stated that most of the calcium levels in the subjects were categorized as high, and there was no significant difference in serum calcium levels between stunting and non-stunting children. Febria et al. ${ }^{19}$ stated that there was no significant relationship between calcium levels in breast milk, breastmilk substitute, and complementary foods with the incidence of stunting. According to Astutik et al., ${ }^{17}$ there is no significant difference between stunting and non-stunting calcium intake. Calcium is not associated with the incidence of stunting.

Based on the results of the analysis of the comparative test of zinc nutrition, the average stunted children were 0.005 grams, and 0.010 grams of non-stunted children had shown zinc adequacy because their needs were $3 \mathrm{mg} /$ day or 0.003 grams/day. In contrast to the research of Aryati et al. ${ }^{4}$ the average zinc intake was $2.89 \mathrm{mg}$, and this figure is still far from the RDA in 2013, which was $4 \mathrm{mg}$.

Zinc is a micromineral that has a role in the enzyme part of the body's metabolism. Zinc also functions in the production of growth hormone and as an antioxidant needed for immune function. Zinc deficiency is associated with suboptimal growth, diarrheal disease, and decreased immune function. ${ }^{4}$ Chronic zinc deficiency can interfere with the central nervous 
system and brain function, interfere with vitamin A metabolism, thyroid gland function, and metabolic rate, can also interfere with appetite, decrease a sense of taste, and slows wound healing. ${ }^{20}$ Food sources high in zinc nutrients are soybeans, red beans, palm sugar, fish, etc.

This study is not following the study by Astutik et al., ${ }^{17}$ which states a relationship between zinc intake and stunting in children under five. Less zinc intake for children under five had a 4.241 times risk of stunting compared to adequate zinc intake for children under five. Leo et al. ${ }^{21}$ stated that the analysis results showed that a low zinc adequacy level was a risk factor for the incidence of stunting in mountain areas with a risk of being stunted 2.827 times.

The GiAS application is following the Purbaningtyas $^{22}$ research states that the application is a mobile-based application that can help independent early detection of the nutritional status of each individual and provide recommendations for daily nutritional intake based on the user's daily calorie needs. The nutritional intake recommendations refer to the standard RDA set by the Ministry of Health of the Republic of Indonesia. ${ }^{14,15}$ Afiana and Yuanita ${ }^{23}$ stated that their application is called GIZIe to monitor anthropometry and nutritional status of children aged o-60 months. Application design focuses on developing health nutrition studies by monitoring the digital mobile nutritional status development using anthropometry. It also provides advice following the development of infant's and toddlers' nutritional status and age. The application follows the GiAS application but differs from the RDA and the graph of macronutrients, zinc, and calcium.

Rahmawati et al. ${ }^{24}$ stated that the toddler nutrition monitoring application could help posyandu officers and toddlers' parents monitor the development of toddler nutrition. Officers enter toddler data from the server application, and parents can monitor the development of toddlers in the form of data and graphics. The information displayed is in the form of the nutritional status of toddlers, whether it is more, less, or significantly less. There is a slight difference in the research, namely in the GiAS application of parents or cadres that enter food memories and the weight and height of children under five.

Hendra and Rahmad ${ }^{25}$ stated that in the study of the nutritional status monitoring application (PSG) for toddlers, it positively impacted and significantly affected the quality and nutrition, especially the nutritional status data for toddlers. The value of the application of the android-based PSG application for toddlers has a better quality value than the conventional use of PSG books. ${ }^{26}$ Also, using an electronic-based system (PSG application for toddlers based on android) is of better quality. Data analysis is more for planning, monitoring, and evaluating nutrition programs and supporting decision-making in dealing with nutritional problems.

Nutrients of carbohydrates, fat, protein, calcium, and zinc were known from filling the recalled food by mothers of stunting and nonstunting children filled in for seven days on application. For parents who do not have a quota or wifi, researchers provide pocketbooks to write children's daily recall food to help mothers not forget. The indicator of success can be seen from the increase in body weight and height in stunting and non-stunting toddlers. On average, there is an increase in body weight and height in both groups after being given the GiAS application at two weeks and one month.

The GiAS application shows menu recommendations that can help mothers or parents of stunting and non-stunting toddlers to prepare food menus for their toddlers so that parents can make food and their nutritional needs are met.

\section{Conclusions}

The GiAS application is an application with the latest 2019 RDA. There are menu recommendations with a composition that is following the $2020 \mathrm{MCH}$ recommendation. The GiAS application makes it easy for parents to know how to compare macronutrients, zinc, and calcium in their children.

\section{Conflict of Interest}

All authors state that there is no conflict of interest in this study.

\section{Acknowledgment}

We want to thank the head of the Citeureup Public Health Center and residents, regional cadres of Citeureup Public Health Center who have toddlers aged 12-24 months who have participated in this research. 


\section{References}

1. Kunayarti W, Julia M, Susilo J. Pengaruh taburia terhadap status anemia dan status gizi balita gizi kurang. J Gizi Klinik Indones. 2014;11(1):38-47.

2. Azmy U, Mundiastuti L. Nutrients consumption of stunted and non-stunted children in Bangkalan. Amerta Nutr. 2018;2(3):292-8.

3. Susilowati, Kuspriyanto. Gizi dalam daur kehidupan. Bandung: Refika Aditama; 2016.

4. Aryati NB, Hanim D, Sulaeman ES. Hubungan ketersediaan pangan keluarga miskin, asupan protein, dan zink dengan pertumbuhan anak umur 12-24 bulan pada siklus 1000 hari pertama kehidupan. MGMI. 2018;9(2):99-112.

5. Kurniasari Y, Juffrie M, Sitaresmi MN, Jamil JD. Kadar kalsium serum pada anak stunting dan tidak stunting usia 24-59 bulan. J Gizi Klinik Indones. 2016;12(3):108-15.

6. Raiten DJ, Bremer AA. Exploring the nutritional ecology of stunting: new approaches to an old problem. Nutrients. 2020;12(2):371.

7. Taher E, Elkoly M, Zaghloul S, Mohammed H. Predictors of stunting among children attending the National Nutrition Institute in Egypt. Egypt $\mathrm{J}$ Community Med. 2018;36(01):45-60.

8. World Health Organization. Infant and young child feeding: model chapter for textbooks for medical students and allied health profesionals. Geneva: World Health Organization; 2013.

9. Setyawati VAV, Hartini E. Buku ajar dasar ilmu gizi kesehatan masyarakat. Sleman: Penerbit Deepublish; 2018.

10. Setiawan W. Era digital dan tantangannya. Paper presented at Seminar Nasional Pendidikan 2017; Sukabumi; 2017 August 9.

11. Nadiyah, Briawan D, Martianto D. Faktor risiko stunting pada anak usia $0-23$ bulan di Provinsi Bali, Jawa Barat, dan Nusa Tenggara Timur. J Gizi Pangan. 2014;9(2):125-32.

12. Wuryanta AGEW. Digitalisasi masyarakat: menilik kekuatan dan kelemahan dinamika era informasi digital dan masyarakat informasi. J Ilmu Komun. 2013;1(2):131-42.

13. Kementerian Kesehatan Republik Indonesia. Buku kesehatan ibu dan anak. 2020 Prints [Internet]. Jakarta: Kementerian
Kesehatan Republik Indonesia; 2020 [cited 2020 January 5]. Available from: https:// kesga.kemkes.go.id/assets/file/pedoman/ BUKU\%2OKIA\%2OTAHUN\%202020\%20 BAGIAN\%2OANAK.pdf.

14. Kementerian Kesehatan Republik Indonesia. Petunjuk pelaksanaan surveilans gizi. Jakarta: Kementerian Kesehatan Republik Indonesia; 2011.

15. Kementerian Kesehatan Republik Indonesia. Pedoman metode melengkapi nilai gizi bahan makanan pada tabel komposisi pangan Indonesia (imputated and borrowed values) [Internet]. Jakarta: Kementerian Kesehatan Republik Indonesia; 2017 [cited 2020 January 5). Available from: https://www. panganku.org/assets/files/publikasi/351bb3 c3b280a7fcd7c864cba56c7917.pd.

16. Ayuningtyas, Simbolon D, Rizal A. Asupan zat gizi makro dan mikro terhadap kejadian stunting pada balita. JK. 2018;9(3):444-9.

17. Astutik, Rahfiludin MZ, Aruben R. Faktor risiko kejadian stunting pada anak balita usia 24-59 bulan (studi kasus di wilayah kerja Puskesmas Gabus II Kabupaten Pati Tahun 2017). JKM. 2018;6(1):409-18.

18. Isnainy DZ, Luthfiyah F, Abdi LK, Sofiyatin R. Konsumsi zat gizi makro pada balita stunting (24-59 bulan). JGP. 2017;2(1):7-13.

19. Febria C, Masrul, Chundrayetti E. Hubungan kadar kalsium dalam ASI, PASI dan MPASI dari asupan bayi dengan panjang badan bayi usia 6-12 bulan di wilayah kerja Puskesmas Lubuk Buaya Padang 2017. JKA. 2017;6(3):662-7.

20. Hall JE. Guyton and Hall textbook of medical physiology. 13th Edition. Philadelphia: Elsevier; 2016.

21. Leo AR, Subagyo HW, Kartasurya MI. Faktor risiko stunting pada anak usia $2-5$ tahun di wilayah gunung dan pesisir pantai. J Gipas. 2018;2(1):51-63.

22. Purbaningtyas R. Penerapan fuctional testing pada uji kelayakan aplikasi mobile smart malnutrition detection. Techno Com. 2019;18(3):251-63.

23. Afiana FN, Yunita IR. Aplikasi "GIZIe" untuk mengetahui status gizi balita menggunakan metode forward chaining 2017. J RESTI. 2019;3(2):297-303.

24. Rahmawati IK, Hasanah H, Maulindar J. Aplikasi monitoring status gizi tubuh balita dengan metode $\mathrm{Z}$ score berbasis android. 
Paper presented at Seminar Nasional Teknologi Informasi dan Bisnis; Surakarta; 2017 November 4.

25. Hendra A, Rahmad A. Pemanfaatan aplikasi standar pertumbuhan WHO 2005 berbasis smartphone android (PSG balita) terhadap kualitas data gizi. JK. 2020;11(1):10-8.
26. Kementerian Kesehatan Republik Indonesia. Buku saku pemantauan status gizi tahun 2017 [Internet]. Jakarta: Kementerian Kesehatan Republik Indonesia; 2018 [cited 2020 July 15]. Available from: https://kesmas.kemkes. go.id/assets/uploads/contents/others/ Buku-Saku-Nasional-PSG-2017_975.pdf. 